\title{
Effects of Slow Release Urea Supplementation of Sheep Protein Source Feed Protected with Condensed Tannin from Leucaena on Protein Degradation in Rumen and Post-rumen In Vitro
}

\author{
Efka Aris Rimbawanto $^{1) *}$, Sri Suhermiyati ${ }^{1)}$ and Bambang Hartoyo ${ }^{1)}$ \\ 1) Faculty of Animal Science, Jenderal Soedirman University JI. Dr. Soeparno No. 60, Purwokerto, Indonesia \\ *Corresponding author email: efka.rimbawanto@unsoed.ac.id
}

\begin{abstract}
The objectives of the research were to supply nitrogen for protein synthesis of ruminal microbe from slow release urea and to supply post-rumen protein from soybean meal protected with condensed tannin (CT) from crude Leucaena leaves extract. In Experiment 1, slow release urea (SRU) was made by extrusion of cassava waste-urea, tapioca meal-urea and cassava meal-urea. Evaluation of SRU properties was based on residual nitrogen concentration and ruminal fermentation products (total volatile fatty acid and ammonianitrogen) in vitro. In Experiment 2, soybean meal protected with CT from crude Leucaena leaves extract as much as 1,68 g tannin/100 g DM soybean meal. SRU that was selected from Experiment 1 was used as the supplement in sheep ration whose protein source was protected with CT. SRU supplement in basal rations was $0,6.36,12.75,19.11 \%$ DM. In vitro result in Experiment 1, showed that SRU of cassava waste, tapioca meal and cassava meal were different $(P<0,01)$ on residual nitrogen content, total VFA, ammonia- $N$, and fermentation time. The optimum SRU obtained from cassava waste by inhibiting nitrogen hydrolysis up to $14 \mathrm{~h}$. In Experiment 2, SRU supplementation of cassava waste on basal ration whose protein source was protected with CT increased dry matter (DM) degradability $(P<0,01)$, total VFA $(P<0,01)$, ammonia-N $(P<0,01)$, and did not affect crude protein (CP) ruminal degradation. Post-ruminal degradability of DM and CP increased $(P<0.01)$ in line with the increasing supplement, and reached the optimum level at $12,75-19,11 \%$ DM. In conclusion, cassava waste was a potent SRU through extrusion process and could be harnessed as SRU supplement in ration with protein source protected with condensed tannin to improve ruminal microbe protein synthesis.

Key words: slow release urea, cassava waste, tannin, leucaena
\end{abstract}

Abstrak. Tujuan penelitian ini adalah penyediaan nitrogen untuk sintesis protein mikroba rumen dari urea lepas lambat dan ketersediaan protein paska rumen dari bungkil kedelai yang diproteksi dengan ekstrak kasar tanin kondensasi daun lamtoro. Dalam percobaan 1, urea lepas lambat dibuat dengan cara ektruksi dari onggok-urea, tepung tapioka-urea dan tepung gaplek-urea. Pengujian sifat urea lepas lambat berdasarkan kadar nitrogen residu dan produk fermentasi rumen (VFA total dan N-amonia) secara in vitro. Dalam percobaan 2, bungkil kedelai diproteksi dengan ekstrak kasar tanin kondensasi daun lamtoro 1,68 g tanin/100 g BK bungkil kedelai. Urea lepas lambat terpilih dari percobaan pertama digunakan sebagai suplemen dalam ransum domba yang sumber proteinnnya diproteksi dengan tanin kondensasi. Suplemen urea lepas lambat pada ransum basal sebanyak $0 ; 6,36 ; 12,75 ; 19,11 \%$ BK. Hasil percobaan in vitro dalam percobaan pertama, ketiga urea lepas lambat dari onggok, tepung tapioka dan tepung gaplek berbeda $(P<0,01)$ terhadap kadar nitrogen residu, VFA total, $\mathrm{N}$-amonia, dan waktu fermentasi. Urea lepas lambat terbaik dari bahan onggok dengan penghambatan waktu hidrolisis nitrogen sampai 14 jam. Dalam percobaan kedua, suplementasi urea lepas lambat dari onggok pada ransum basal yang sumber proteinnya diproteksi tanin kondensasi meningkatkan degradasi bahan kering $(P<0,01)$, VFA total $(P<0,01), N$-amonia $(P<0,01)$, dan tidak berpengaruh terhadap degradasi protein kasar di dalam rumen. Degradasi bahan kering dan protein kasar di paska rumen meningkat $(P<0,01)$ dengan meningkatnya suplemen dan terbaik pada level $12,75-19,11 \%$ BK. Disimpulkan bahwa onggok dapat digunakan sebagai urea lepas lambat melalui proses ektrusi dan dapat digunakan sebagai suplemen urea lepas lambat pada ransum yang sumber proteinnya diproteksi dengan tanin kondensasi dalam meningkatkan sintesis protein mikroba rumen.

Kata kunci: urea lepas lambat, onggok, tanin, lamtoro

\section{Introduction}

The quantity of protein feed is the determining factor of ruminant productivity, and the supply is dependent on rumen- undegradable protein and efficiency of microbial protein synthesis (Owens et al., 2014). Microbial protein synthesis can supply $50 \%$ protein need in cattle (Seo et al., 2013) and the 
rest is from the rumen undegradable protein (NRC, 1985). Twenty to thirty percent of protein-enriched feedstuff (soybean meal) in ruminant feed is rumen undegradable (NRC, 1985). The decreasing rumen-degradable protein will improve the quality of post-ruminal protein digestibility. Tannin can be utilized to protect the protein against ruminal degradation (Theodoridou et al., 2010) and to lower ruminal ammonia level in vitro (Cortes et al., 2009).

Tannin-protein complex may inhibit extracellular enzyme of proteolytic microbe (Alonzo-Diaz et al., 2010) or ruminal metabolite product, therefore affecting several proteolytic bacteria (Wang et al., 2009). Proteolysis inhibition occurs because phenolic compounds cover protein surface, therefore it obstructs enzyme and substrate interaction (Anantasook et al., 2013). Condensed tannin form $1 \mathrm{~g}$ Leucaena leaves can bind $26.25 \mathrm{~g}$ protein bovine serum albumin (Rimbawanto et al., 2015).

The inhibition of ruminal-degradable protein feed decreases ammonia-N supply for microbial protein synthesis. Urea supplement in ruminant feed can supply ammonia- $\mathrm{N}$ but easily hydrolyzed in the rumen due to urease activity of ruminal microbe that exceeds the capacity of microbial protein synthesis (Cherdthong and Wanapat, 2010). Optimizing urea utilization can be inhibited by the rate of hydrolysis of urea into ammonia- $\mathrm{N}$ in the rumen. Inhibiting hydrolysis is conducted by mixing urea with gelatin (Paengkoum and Bunnakit, 2012). Ureagelatin as SRU provides both nitrogen and energy from gelatin for microbial protein synthesis. The use of SRU in feed is evidenced to affect milk production and feed digestibility of dairy cattle (Sinclair et al., 2012) but does not affect digestibility and digestibility rate of beef cattle fed with low concentrate (Benedeti et al., 2014).

The objectives of the study were to evaluate the properties of SRU of urea-gelatin with gelatin source derived from cassava waste, tapioca meal and cassava meal according to the inhibition of ruminal nitrogen hydrolysis and the effect of slow release urea from ureagelatin in the sheep ration with rumenundegradable protein based on protein supply in the rumen and post-rumen in vitro.

\section{Materials and Methods}

SRU sample was made of cassava waste, tapioca meal, and cassava meal as the source of starch mixed with urea with the ratio of starch and urea was $85: 15 \mathrm{DM}(44 \% \mathrm{CP})$. The three materials were made through the extrusion process using extruder (single screw extruder), a cooker-extruder at $100^{\circ} \mathrm{C}, 20 \%$ moisture, screw rate of $70 \mathrm{rpm}$, and pelleted $0,76 \mathrm{~cm}$. Three SRU for NPN feed sources (cassava waste-urea, tapioca meal-urea and cassava meal-urea).

Tannin extraction was conducted using Soxhlet, each of $5 \mathrm{~g}$ DM Leucaena powder was put in timble (Whatman $25 \times 100 \mathrm{~mm}$ ) with 150 $\mathrm{ml}$ dissolvent which was $70 \%$ acetone containing 1\% HCL (Chavan et al., 2001; Shahidi and Naczk, 2004). Heating temperature was adjusted to 6-time dissolution in $1 \mathrm{~h}$ and extraction was conducted for $3 \mathrm{~h}$. Crude extract solution was thickened with rotary evaporator at $\leq 80^{\circ} \mathrm{C}$ to optimize component degradation. Soybean meal protected with tannin was made by spraying soybean meal with condensed tannin from Leucaena leaves extract $(1.68 \mathrm{~g}$ condensed tannin from lamtoro leaves/100 g DM soybean meal) then air-dried.

Ruminal fluid was derived from three sheep fed with 70\% DM Pennisetum purpureum and 30\% DM concentrate given at 07.00 and 15.00 ad libitum. Ruminal fluid was taken in the morning before feeding, filtered then added with buffer McDougall at $39^{\circ} \mathrm{C}$ with ratio $1: 4$ (v/v) as inoculum source.

Experiment 1 tested SRU in vitro derived from different gelatin sources including cassava 
waste, tapioca-meal and cassava-meal according to Tilley and Terry (1963). Anaerobic incubation was performed at $0,2,4,6,10,14$, 22,30 , and $48 \mathrm{~h}$, with 5 replicates. In each incubation, residue was analyzed for total nitrogen concentration (AOAC, 2002) and the supernatant was analyzed for total VFA (chromatograph gas) and ammonia- $\mathrm{N}$ with phenol-hypochlorite reaction (Weatherburn, 1967). The obtained data were subject to analysis of variance in completely randomized design. Should different mean value occur, Duncan's multiple range test was conducted using IBM SPSS Statistics program ver. 23.

In vitro experiment 2 used SRU supplement from Experiment 1 as much as 0, 6.36, 12.75 and $19.11 \%$ DM basal ration (Table 1). In vitro experiment was conducted according to Tilley and Terry (1963). Incubation was performed for $96 \mathrm{~h}$, each treatment was repeated 5 times. Glass tube consisted of two sets; first tube had $48 \mathrm{~h}$ anaerobic incubation then added with $1 \mathrm{ml}$ mercuric chloride $(50 \mathrm{mg} / \mathrm{ml})$, second tube was added with $6 \mathrm{ml} \mathrm{HCl} 20 \%(\mathrm{v} / \mathrm{v})$ then aerobic incubation continued for $48 \mathrm{~h}$. The content of the first tube was filtered, then the sediment was analyzed for dry matter, total nitrogen (AOAC, 2002), and the supernatant was analyzed for total VFA (chromatograph gas) and ammonia- $\mathrm{N}$ using phenol-hypochlorite reaction (Weatherburn, 1967). The content of the second tube after $48 \mathrm{~h}$ aerobic incubation was filtered and the sediment was analyzed for dry matter and total nitrogen (AOAC, 2002). The obtained data were subject to analysis of variance in completely randomized design. Should different mean value occur, Duncan's multiple range test was conducted using IBM SPSS Statistics program ver. 23.

\section{Results and Discussions}

\section{Nitrogen level of slow release urea}

The result of proximate analysis in making SRU with extruder from cassava waste, tapioca meal and cassava-meal is presented in Table 2. The highest nitrogen content of SRU was in urea-tapioca meal, urea-cassava meal and ureacassava waste. Different starch content between cassava waste, tapioca meal and cassava meal made the different amount of ingredients to make SRU. Accordingly, different nitrogen content were due to different component of carbohydrate which is bigger in cassava waste than in cassava-meal and tapioca-meal.

\section{Effect of SRU on nitrogen hydrolysis during in vitro fermentation}

Residual nitrogen was used as the indicator of nitrogen that was not hydrolyzed by urease produced by ruminal microbe. The effect of different fermentation time of SRU on residual nitrogen is presented in Table 3. Result of SRU solubility test in vitro showed that different ingredients affected residual nitrogen when making SRU $(P<0.01)$ and the duration of fermentation $(P<0.01)$.

Table 1. Ingredient composition of the experimental feeds on dry matter basis (\% DM)

\begin{tabular}{lcccc}
\hline Ingredient & R1 & R2 & R3 & R4 \\
\hline Rice straw, \%DM & 70.00 & 70.00 & 70.00 & 70.00 \\
Protected Soybean meal, \%DM & 15.00 & 15.00 & 15.00 & 15.00 \\
Cassava waste, \%DM & 15.00 & 15.00 & 15.00 & 15.00 \\
Slow release urea, \%DM & - & 6.36 & 12.75 & 19.11 \\
\hline
\end{tabular}

$\mathrm{R} 1$ = basal ration, $\mathrm{R} 2$ = basal ration + 6.36 \% DM SRU, R3 = basal ration + 12.75 \% DM SRU, R4 = basal ration + $19.11 \% \mathrm{DM}$ SRU 
Table 2. Chemical composition of the SRU from cassava waste, tapioca-meal, and cassava meal (\%DM)

\begin{tabular}{lccc}
\hline & Cassava waste & Tapioca meal & Cassava meal \\
\hline Dry matter & 83.45 & 91.00 & 90.13 \\
Ether extract & 1.09 & 0.61 & 0.71 \\
Crude fiber & 34.56 & - & 5.67 \\
Ash & 6.13 & 0.25 & 4.74 \\
Nitrogen free extract & 55.34 & 98.21 & 86.26 \\
Nitrogen & 5.03 & 6.67 & 5.86 \\
Starch & 38.29 & 85.46 & 69.93 \\
\hline
\end{tabular}

Table 3. Mean value of residual nitrogen (\% N) SRU of cassava waste, tapioca meal and cassava meal on the duration of fermentation in different rumen in vitro

\begin{tabular}{ccccc}
\hline \hline Incubation time & Cassava waste & Tapioca meal & Cassava meal & Mean \\
\hline 0 & $26.50 \pm 1.68$ & $29.46 \pm 1.76$ & $24.36 \pm 0.42$ & $26.77 \pm 2.56^{\mathrm{f}}$ \\
2 & $16.56 \pm 0.70$ & $25.94 \pm 2.99$ & $22.68 \pm 0.46$ & $21.73 \pm 4.76^{\mathrm{e}}$ \\
4 & $13.36 \pm 3.30$ & $23.63 \pm 1.21$ & $20.64 \pm 1.34$ & $19.21 \pm 5.28^{\mathrm{de}}$ \\
6 & $11.25 \pm 0.80$ & $21.28 \pm 1.17$ & $15.97 \pm 2.74$ & $16.17 \pm 5.02^{\mathrm{cd}}$ \\
10 & $10.06 \pm 1.31$ & $19.18 \pm 1.55$ & $13.72 \pm 1.93$ & $14.32 \pm 4.59^{\mathrm{bc}}$ \\
14 & $7.88 \pm 0.15$ & $18.74 \pm 1.13$ & $11.05 \pm 1.21$ & $12.56 \pm 5.59^{\mathrm{ab}}$ \\
22 & $6.63 \pm 1.78$ & $17.91 \pm 1.02$ & $8.41 \pm 0.56$ & $10.98 \pm 6.06^{\mathrm{ab}}$ \\
30 & $5.94 \pm 0.48$ & $17.10 \pm 1.21$ & $7.88 \pm 0.82$ & $10.31 \pm 5.96^{\mathrm{a}}$ \\
48 & $5.73 \pm 0.67$ & $15.77 \pm 1.62$ & $6.72 \pm 0.32$ & $9.41 \pm 5.53^{\mathrm{a}}$ \\
\hline Mean & $11.55 \pm 6.68^{\mathrm{a}}$ & $21.00 \pm 4.52^{\mathrm{b}}$ & $14.60 \pm 6.69^{\mathrm{c}}$ &
\end{tabular}

Note: abcdef Different superscripts within row and column show a considerably significant difference $(\mathrm{P}<0.05)$.

The decreasing residual nitrogen was due to different nitrogen-urea bound in starch during gelatinization in the extruder. Different starch level also resulted in different amount of ingredients added to the urea, and non-starch nutrients were also different particularly in terms of crude fiber level. The level of crude fiber which contributed to the amount of bound nitrogen urea in the starch during gelatinization was different across ingredients. Nitrogen urea absorbed in the crude fiber in rumen would be soluble. The increasing fermentation time decreased residual nitrogen because nitrogen served as the source of ammonia- $\mathrm{N}$ for microbial protein synthesis. The inhibited hydrolysis by ruminal microbe during fermentation in vitro was effective because it supported microbial protein synthesis up to 14 $h$ fermentation and did not change $(P>0.05)$ until $48 \mathrm{~h}$.

\section{The effect of SRU on fermentation products in vitro}

Different effects of SRU on ruminal microbe fermentation products (ammonia- $\mathrm{N}$ and total VFA) are presented in Table 4. Ammonia-N level and total VFA of ruminal liquid were affected $(P<0.01)$ by different components of SRU and fermentation time.

The highest mean of ammonia- $\mathrm{N}$ was found in cassava waste based SRU $(9.89 \pm 3.47 \mathrm{mg} /$ $100 \mathrm{ml})$ in comparison to tapioca meal $(8.74 \pm$ $3.02 \mathrm{mg} / 100 \mathrm{ml})$ and cassava meal $(8.09 \pm 2.65$ $\mathrm{mg} / 100 \mathrm{ml}$ ). Ammonia- $\mathrm{N}$ levels of the three 
SRU could support ruminal microbe protein synthesis. The optimum ruminal microbe protein synthesis was obtained with $5-8$ $\mathrm{mg} / 100 \mathrm{ml}$ ammonia in ruminal liquid (Satter and Slyter, 1974). The increase of ammonia-N level occurred at $14 \mathrm{~h}$ fermentation $(\mathrm{P}<0.05)$ in vitro, and remained steady after $14 \mathrm{~h}(\mathrm{P}>0.05)$. The increasing ammonia- $\mathrm{N}$ up to $14 \mathrm{~h}$ fermentation showed an inhibited nitrogenurea hydrolysis in the rumen of the three SRUs. Nitrogen-urea extrusion process with cassava waste, tapioca meal and cassava meal could inhibit the process of ruminal nitrogen hydrolysis in vitro, therefore supplying ammonia-N for microbial protein synthesis.

Total VFA of cassava waste-based SRU (188 \pm $23.5 \mathrm{mM} / \mathrm{l})$ was higher than that of cassava meal (182 $\pm 20.4 \mathrm{mM} / \mathrm{l})$ and tapioca meal (176 \pm $19.1 \mathrm{mM} / \mathrm{l})$ because of different level of crude fiber despite equal starch level across the ingredients. Fiber fermentation product of ruminal microbe is acetic acid that affects total VFA. Reddy and Reddy (2015) stated that extrusion would increase crude fiber digestibility from feedstuff mixed with urea for ruminants. Total VFA across SRUs increased up to $14 \mathrm{~h}$ fermentation $(\mathrm{P}<0.01)$ in vitro, but remained steady between 14 and $48 \mathrm{~h}$ ( $P>0.05)$.

Inhibition of nitrogen-urea inhibition of the three SRUs by ruminal microbe urease enzyme occurred during $14 \mathrm{~h}$ in vitro fermentation. After $14 \mathrm{~h}$, fermentation products of ammonia$\mathrm{N}$ and total VFA had inhibited microbial protein synthesis. In contrast with in vivo experiment in which ruminal microbe fermentation products undergo metabolism in rumen, in vitro ruminal microbe fermentation products is toxic to ruminal microbe when reaching optimum level. Accordingly, cassava waste-based SRU was selected as SRU because of the high availability and cheaper price compared to tapioca meal and cassava meal.
Effect of SRU supplementation in feed with protein source protected with condensed tannin on protein ruminal and post-ruminal degradation in vitro

SRU was selected from cassava waste as the supplement of basal ration with protein source protected by condensed tannin from Leucaena leaves. Chemical properties of basal ration supplemented with different level of SRU are presented in Table 5. The DM of SRU was rich in crude protein, crude fiber and nitrogen free extract. SRU supplementation in basal ration increased the level of other nutrients compared to basal ration.

The effects of SRU supplementation in basal ration with protein source protected with condensed tannin from Leucaena leaves on DM and $\mathrm{CP}$ degradation, ruminal fermentation product and total degradation in $\mathrm{HCl} /$ pepsin (post-rumen) are presented in Table 6. SRU supplementation increased DM ruminal degradation $(P<0.01)$ without affecting $C P$ ruminal degradation $(P>0.05)$ in vitro. Total VFA $(P<0.05)$ and ammonia- $N(P<0.01)$ in ruminal fermentation product also increased along with the increasing SRU supplement. Total degradation (post rumen) increased the degradation of $D M(P<0.01)$ and $C P(P<0.01)$.

The increasing $D M$ degradation in basal ration supplemented with SRU compared to the control feed showed that SRU can be harnessed as nitrogen source for ruminants. Slow release urea from cassava waste can increase energy and nitrogen supply for microbial protein synthesis indicated from the increasing ruminal total VFA and ammonia-N in vitro. Synchronizing energy and nitrogen supply in rumen would improve microbial protein synthesis (Seo et al., 2013). CP degradation in ruminal fluid between control ration and supplemented ration was not different, indicating that soybean meal protected with condensed tannin from lamtoro leaves was effective. Complex bound of protein-tannin would inhibit proteolytic bacteria and 
proteolytic enzyme activity (Wang et al., 2009; Alonzo-Diaz et al., 2010). Although condensed tannin inhibited proteolytic enzyme activity, SRU supplement could increase microbial protein synthesis as indicated from the increasing ammonia- $\mathrm{N}$ concentration in ruminal fluid.

DM degradation in rumen was followed by the increasing DM degradation post-rumen in basal ration supplemented with SRU compared to that in control. It showed that SRU supplement was effective to increase ruminal microbe growth and activity. Post-ruminal CP degradation in control ration $(72,10 \% \mathrm{CP})$ showed that soybean meal protected with condensed tannin was effective to increase post-ruminal $\mathrm{CP}$ availability. CP degradation increased in basal ration supplemented with SRU, indicating a supply from microbial protein. The highest CP level was obtained at 12.75 19.11\% DM SRU with the ratio of SRU and protected soybean meal was 46 : 54\% DM.

Table 4. Mean value of ammonia- $\mathrm{N}$ product $(\mathrm{mg} / 100 \mathrm{ml}) \mathrm{SRU}$ of cassava waste, tapioca meal, and cassava meal on fermentation time in different rumen in vitro

\begin{tabular}{|c|c|c|c|c|c|c|c|c|}
\hline \multirow[b]{2}{*}{$\begin{array}{l}\text { Incubation } \\
\text { time }\end{array}$} & \multicolumn{4}{|c|}{ Ammonia-N (mg/100 ml) } & \multicolumn{4}{|c|}{ Total VFA (mmol/l) } \\
\hline & $\begin{array}{l}\text { Cassava } \\
\text { waste }\end{array}$ & $\begin{array}{c}\text { Tapioca } \\
\text { meal }\end{array}$ & $\begin{array}{c}\text { Cassava } \\
\text { meal }\end{array}$ & Mean & $\begin{array}{c}\text { Cassava } \\
\text { waste }\end{array}$ & $\begin{array}{c}\text { Tapioca } \\
\text { meal }\end{array}$ & $\begin{array}{c}\text { Cassava } \\
\text { meal }\end{array}$ & Mean \\
\hline 0 & $4.00 \pm 0.55$ & $4.00 \pm 1.55$ & $4.00 \pm 1.05$ & $4.00 \pm 0.00^{\mathrm{a}}$ & $140 \pm 6.7$ & $140 \pm 2.0$ & $140 \pm 2.0$ & $140 \pm 0.0^{a}$ \\
\hline 2 & $5.32 \pm 0.93$ & $5.15 \pm 0.67$ & $4.88 \pm 1.53$ & $5.12 \pm 0.22^{\mathrm{b}}$ & $164 \pm 2.1$ & $153 \pm 3.1$ & $167 \pm 4.2$ & $161 \pm 7.4^{b}$ \\
\hline 4 & $7.27 \pm 0.55$ & $6.65 \pm 1.53$ & $6.03 \pm 0.96$ & $6.65 \pm 0.62^{c}$ & $176 \pm 0.0$ & $170 \pm 2.0$ & $176 \pm 1.7$ & $174 \pm 3.5^{c}$ \\
\hline 6 & $10.36 \pm 1.70$ & $7.53 \pm 1.53$ & $7.09 \pm 1.32$ & $8.33 \pm 1.77^{d}$ & $189 \pm 7.8$ & $173 \pm 2.3$ & $179 \pm 7.0$ & $180 \pm 8.1^{d}$ \\
\hline 10 & $11.24 \pm 1.53$ & $9.30 \pm 1.53$ & $8.86 \pm 0.76$ & $9.80 \pm 1.27 \mathrm{e}$ & $195 \pm 9.0$ & $179 \pm 1.2$ & $189 \pm 3.1$ & $188 \pm 8.1^{\mathrm{e}}$ \\
\hline 14 & $12.03 \pm 1.46$ & $11.06 \pm 1.32$ & $10.18 \pm 0.76$ & $11.09 \pm 0.93^{f}$ & $205 \pm 2.3$ & $187 \pm 3.1$ & $193 \pm 5.8$ & $195 \pm 9.2^{f}$ \\
\hline 22 & $12.83 \pm 0.76$ & $11.68 \pm 1.00$ & $10.45 \pm 0.67$ & $11.65 \pm 1.19^{f}$ & $206 \pm 2.0$ & $193 \pm 5.8$ & $198 \pm 1.5$ & $199 \pm 6.6^{f}$ \\
\hline 30 & $12.83 \pm 1.53$ & $11.68 \pm 1.70$ & $10.89 \pm 0.31$ & $11.80 \pm 0.98^{f}$ & $207 \pm 7.6$ & $195 \pm 6.1$ & $197 \pm 5.8$ & $200 \pm 6.4^{f}$ \\
\hline 48 & $13.09 \pm 0.67$ & $11.68 \pm 1.22$ & $10.45 \pm 0.67$ & $11.74 \pm 1.32^{f}$ & $207 \pm 3.1$ & $192 \pm 5.3$ & $197 \pm 5.8$ & $199 \pm 7.6^{f}$ \\
\hline Mean & $9.89 \pm 3.47^{a}$ & $8.74 \pm 3.02^{b}$ & $8.09 \pm 2.65^{c}$ & & $188 \pm 23.5^{a}$ & $176 \pm 19.1^{b}$ & $182 \pm 20.4^{c}$ & \\
\hline
\end{tabular}

abcdef Different superscripts within row and column show a considerably significant difference $(P<0.05)$

Table 5. Chemical composition ration in the experiment (\% DM)

\begin{tabular}{lrrrr}
\hline & R1 & \multicolumn{1}{c}{ R2 } & \multicolumn{1}{c}{ R3 } & \multicolumn{1}{c}{ R4 } \\
\hline Dry matter & 64.44 & 69.75 & 75.08 & 80.39 \\
Crude protein & 10.00 & 12.00 & 14.00 & 16.00 \\
Ether extract & 5.52 & 5.59 & 5.66 & 5.73 \\
Crude Fiber & 29.01 & 31.20 & 33.41 & 35.61 \\
Ash & 39.23 & 39.62 & 40.01 & 40.40 \\
Nitrogen free extract & 16.24 & 17.95 & 19.66 & 21.36
\end{tabular}

$\mathrm{R} 1$ = basal ration, $\mathrm{R} 2$ = basal ration + 6.36 \% DM SRU, R3 = basal ration + $12.75 \% \mathrm{DM}$ SRU, R4 = basal ration + $19.11 \% \mathrm{DM}$ SRU 
Table 6. In vitro dry matter, crude protein degradation, and product total VFA, ammonia-N $\left(\mathrm{NH}_{3}-\mathrm{N}\right)$ during $48 \mathrm{~h}$ incubation in ruminal fluid (rumen) or ruminal fluid followed by $\mathrm{HCl} /$ pepsin (post rumen) on SRU supplementation in basal ration with soybean meal protected with CT of Leucaena leaves.

\begin{tabular}{|c|c|c|c|c|c|c|}
\hline \multirow[b]{2}{*}{$\begin{array}{l}\text { Ration } \\
\text { treatment }\end{array}$} & \multicolumn{4}{|c|}{ Rumen } & \multicolumn{2}{|c|}{ Post-rumen } \\
\hline & $\begin{array}{c}\text { DM } \\
\text { degradation } \\
(\%)\end{array}$ & $\begin{array}{c}\mathrm{CP} \\
\text { degradation } \\
(\%)\end{array}$ & $\begin{array}{c}\text { Total VFA } \\
(\mathrm{mM} / \mathrm{l})\end{array}$ & $\begin{array}{c}\mathrm{NH}_{3}-\mathrm{N} \\
(\mathrm{mg} / 100 \mathrm{ml})\end{array}$ & $\begin{array}{c}\text { DM } \\
\text { degradation } \\
(\%)\end{array}$ & $\begin{array}{c}C P \\
\text { degradation } \\
(\%)\end{array}$ \\
\hline $\mathrm{R}_{1}$ & $40.11^{\mathrm{a}}$ & 47.26 & $205^{\mathrm{a}}$ & $7.051^{\mathrm{a}}$ & $51.99^{\mathrm{a}}$ & $72.10^{\mathrm{a}}$ \\
\hline $\mathrm{R}_{2}$ & $52.91^{b}$ & 51.63 & $214^{\mathrm{ab}}$ & $11.634^{b}$ & $65.29^{b}$ & $79.12^{b}$ \\
\hline $\mathrm{R}_{3}$ & $58.39^{\mathrm{bc}}$ & 51.57 & $234^{\mathrm{ab}}$ & $14.628^{c}$ & $69.09^{b c}$ & $83.18^{c}$ \\
\hline $\mathrm{R}_{4}$ & $60.82^{c}$ & 51.52 & $248^{\mathrm{ab}}$ & $16.767^{c}$ & $70.79^{c}$ & $84.57^{c}$ \\
\hline Significance & $<0.01$ & 0.015 & $<0.05$ & $<0.01$ & $<0.01$ & $<0.01$ \\
\hline
\end{tabular}

\section{Conclusion}

Cassava waste is potential to produce SRU through extrusion process and can be harnessed as supplement in ruminant feed. SRU supplementation in ration with protein source protected with condensed tannin does not inhibit the activity of microbial protein synthesis in rumen and increases post-ruminal supply of microbial protein.

\section{References}

Alonso-Díaz, M.A., J.F.J. Torres-Acosta, C.A. Sandoval-Castro, and H. Hoste. 2010. Tannins in tropical tree fodders fed to small ruminants: A friendly foe. Small Ruminant Research 89: 164173.

Anantasook, A., M. Wanapat, A. Cherdthong, and P. Gunun. 2013. Changes microbial population in the rumen of dairy steer as influenced by plant containing tannins and saponins and roughage to concetrate ratio. Asian Australasian Journal of Animal Science 26(11):1583-1591.

AOAC. 2002. Official Methods of Analysis. $17^{\text {th }}$ Edition. Asociation of Official Analytical, Washington DC, USA. 684 pages.

Benedeti, P.D.B., P.V.R. Paulino, M.L. Marcondes, S.C.V. Filho, T.S. Martins, E.F. Lisboa, L.H.P. Silva, C.R.V. Teixeira and M.S. Duarte. 2014. Soybean meal replaced by slow release urea in finishing diets for beef cattle. Livestock Science 165: 5160.
Chavan, U.D., F. Shahidi, and M. Naczk. 2001. Extraction of condensed tannins from beach pea (Lathyrus maritimus L.) as affected by different solvents. Food Chemistry 75: 509-512.

Cherdthong, A. and M. Wanapat. 2010. Development of urea product as rumen slow release feed for ruminant production. Austalian Journal of Basic and Applied Sciences 4(8):22322241.

Cortés, J.E., B. Moreno, M.L. Pabón, P. Avila, M. Kreuzer, H.D. Hess, and J.E. Carulla. 2009. Effects of purified condensed tannins extracted from Calliandra, Flemingia and Leucaena on ruminal and postruminal degradation of soybean meal as estimated in vitro. Animal Feed Science and Technology 151: 194-204.

NRC. 1985. Ruminant nitrogen usage. National Academy Press, Washington, DC. 92 pages.

Owens, F.N., S. Qi, and D.A. Sapienza. 2014. Invited Review: Applied protein nutrition of ruminantscurrents status and future directions. The Professional Animal Scientiest 30: 150-179.

Paengkoum, P. And K. Bunnakit. 2012. Nutritional evaluation of extrusion-processed mixture of cassava pulp and urea using in vitro gas production technique. Animal Nutrion and Feed Technology 12: 315-324.

Reddy, G.V.N. and Y.R. Reddy. 2015. Extrusion Technology. In: Kundu, S.S., S.K. Mahanta, S. Singh, and P.S. Pathak (eds). Animal Feed Technology. Satish Serial Publishing House, New Delhi. Pp. 311-326.

Rimbawanto, E.A., L.M. Yusiati, E. Baliarti and R. Utomo. 2015. The effect of condensed tannin of leucaena and calliandra leaves in protein trash fish silage on in vitro ruminal fermentation, 
microbial synthesis and digestibility. Journal of Animal Production 17(2): 83-91.

Sahidi, F. and M. Naczk. 2004. Phenolics in Food and Nutraceuticals. CRC Press. Washington, D.C. 576 pages.

Satter, L. D. and L. L. Slyter. 1974. Effect of ammonia concentration of rumen microbial protein production in vitro. British Journal of Nutrition 32: 199-208.

Seo, J. K., M. H. Kim, J. Y. Yang, H. J. Kim, C. H. Lee, K. H. Kim and J. K. Ha. 2013. Effects of synchronicity of carbohydrate and protein degradation on rumen fermentation characteristics and microbial protein synthesis. Asian-Australia Journal of Animal Science 26: 358-365.

Sinclair, L. A., C.W. Blake, P. Griffin and G.H. Jones. 2012. The partial replacement of soybean meal and rapeseed meal with feed grade urea or a slow-release urea and its effect on the performance, metabolism and digestibility in dairy cows. Animal 6: 920-927.
Theodoridou, K., J. Aufrère, D. Andueza, J. Pourrat, A. L. Morvan, E. Stringano, I. Mueller-Harvey and R. Baumont. 2010. Effects of condensed tannins in fresh sainfoin (Onobrychis viciifolia) on in vivo and in situ digestion in sheep. Animal Feed Science and Technology 160: 23-38.

Tilley, J.M.A. and R.A. Terry. 1963. A two-stage technique for the in vitro digestion of forage crops. Journal of the British Grassland Society 18 (2): $104-111$.

Wang, Y., T.W. Alexander, and T.A. McAllister. 2009. In vitro effects of phlorotannins from Ascophyllum nodosum (brown seaweed) on rumen bacterial populations and fermentation. Journal of the Science of Food and Agricultural 89: 2252-2260.

Wheatherburn, M.W. 1967. Fenol-hypoclorite reaction for determination of ammonia. Analytical Chemmistry 39: 971-974. 